\title{
Saline stress and temperatures on germination and vigor of Piptadenia moniliformis Benth. seeds
}

\author{
Francisco E. C. B. Pereira ${ }^{1}$, Sebastião Medeiros Filho' ${ }^{2}$, Salvador B. Torres ${ }^{3}$, \\ Cibele C. Martins ${ }^{1} \&$ Selma F. de Brito ${ }^{2}$ \\ ${ }^{1}$ Universidade Estadual Paulista Júlio de Mesquita Filho/Faculdade de Ciências Agrárias e Veterinárias/Departamento de Produção Vegetal. Jaboticabal, \\ SP. E-mail: eldercarlos12@gmail.com; cibele@fcav.unesp.br \\ ${ }^{2}$ Universidade Federal do Ceará/Centro de Ciências Agrárias/Departamento de Fitotecnia. Fortaleza, CE. E-mail: filho@ufc.br; crselma@hotmail.com \\ ${ }^{3}$ Universidade Federal Rural do Semiárido/Departamento de Ciências Vegetais. Mossoró, RN. E-mail: sbtorres@ufersa.edu.br (Corresponding author)
}

Key words:

Fabaceae

catanduva

forest seeds

salinity

\begin{abstract}
A B S T R A C T
The knowledge concerning the physiology of germination in saline areas may contribute to the development of more efficient cultural practices and adequate choice of planting areas. Thus, the objective of this study was to evaluate the effects of saline and temperature stress on germination and vigor of Piptadenia moniliformis (a species known in Brazil as "catanduva") seeds. The treatments were distributed according to a completely randomized design in accordance with a $3 \times 6$ factorial arrangement (temperature $\mathrm{x}$ osmotic potential), with four replicates of 25 seeds each. The seeds were put to germinate at constant temperatures of 25 , 30 , and $35^{\circ} \mathrm{C}$ on paper towel moistened in distilled water $(0.0)$ and $\mathrm{NaCl}$ solutions at 0.2 , $0.4,0.6,0.8$ and 1.0 MPa. The results were evaluated in terms of germination percentage and germination speed index, seedling (root and shoot) length, and total dry matter. $P$. moniliformis seeds were able to germinate under temperatures of 25 and $30{ }^{\circ} \mathrm{C}$ and tolerate osmotic potentials of up to $-0.6 \mathrm{MPa}$; from this point on, there is progressive decrease in the physiological quality of seedlings.
\end{abstract}

\section{Palavras-chave:}

Fabaceae

catanduva

sementes florestais

salinidade

\section{Estresse salino e temperaturas na germinação e vigor de sementes de Piptadenia moniliformis Benth}

\section{R E S U M O}

O conhecimento da fisiologia da germinação em locais salinos pode contribuir para o desenvolvimento do manejo e da escolha adequada das áreas de plantio. Com isto objetivou-se avaliar o efeito do estresse salino e temperaturas na germinação e vigor de sementes de catanduva (Piptadenia moniliformis Benth.). O delineamento experimental foi o inteiramente casualizado, com os tratamentos distribuídos em esquema fatorial $3 \mathrm{x}$ 6 (temperatura x potencial osmótico) em quatro repetições de 25 sementes. Para tal, as sementes foram colocadas para germinar nas temperaturas constantes de 25,30 e $35^{\circ} \mathrm{C}$ e semeadas em substrato de papel toalha umedecido com água destilada $(0,0)$ e soluções de $\mathrm{NaCl}$ a - 0,$2 ;-0,4 ;-0,6 ;-0,8$ e -1,0 Mpa; as variáveis analisadas foram a porcentagem e o índice de velocidade de germinação, comprimento de plântulas (raiz e parte aérea) e massa seca total; as sementes de $P$. moniliformis germinadas sob temperaturas de 25 e $30{ }^{\circ} \mathrm{C}$ suportam concentrações salinas com potencial osmótico de até -0,6 MPa sendo que a partir de então ocorre diminuição progressiva da qualidade fisiológica das plântulas. 


\section{INTRODUCTION}

P. moniliformis stands out among the trees native to the Caatinga and is known by the popular names of 'catanduva', 'catanduba', 'rama-de-bezerro' and 'angico-de-bezerro' (Lorenzi, 2002; Azerêdo et al., 2010). According to these authors, this species occurs from the state of Maranhão until Bahia and is more frequent in the region of the São Francisco River Valley. It is a species abundant in this biome, with pioneering characteristics, rustic, with fast growth and indicated for reforestation, besides having potential for forage, apiculture, medicine and timber. In general, the salinity of the substrate or irrigation water causes reduction in soil water potential and toxicity to seed cells (Guan et al., 2009). Situations of salinity, of either soil or water, are more common in semiarid regions, since water availability is limited during a certain period of the year, which compromises germination, establishment of seedlings and their survival (Martins et al., 2014).

One of the most widespread methods for the determination of plant tolerance to the excess of salts is the observation of germination percentage in saline substrates (Lima \& Torres, 2009). According to Góis et al. (2008), the reduction in germinating power, compared with the control treatment, obtained through seeding in substrate moistened with water, serves as an indicator of the salinity tolerance index of the species. In this method, the ability to germinate also indicates the tolerance of the plants to salts in subsequent development stages (Oliveira et al., 2007).

Another environmental factor that affects germination performance, especially if associated with salinity, is temperature. These factors in association affect speed and germination, because they influence water absorption speed and biochemical reactions of the germination process (Guan et al., 2009; Betoni et al., 2011).

Given the above, this study aimed to evaluate the influence of saline stress at different temperatures on the germination and vigor of $P$. moniliformis seeds.

\section{Material ANd Methods}

P. moniliformis seeds were harvested from eighteen parent trees located at the Não-Me-Deixes Farm, in Quixadá-CE, Brazil ( $4^{\circ} 49^{\prime} 34^{\prime \prime}$ S; $38^{\circ} 58^{\prime}$ 9" W; 210 m) from July to August 2014. The climate of the municipality is classified as semiarid hot tropical, with mean annual rainfall of $838.1 \mathrm{~mm}$, concentrated in the months of February to April, and mean temperature of 26 to $28^{\circ} \mathrm{C}$ (IPECE, 2005).

After fruit harvest, the seeds were extracted, manually processed and dried in the shade, for three days. Then, the seeds were placed in polyethylene bags and stored in a cold chamber $\left(12^{\circ} \mathrm{C}\right.$ and $\left.50 \% \mathrm{RH}\right)$.

Before the germination test, the seeds were subjected to chemical scarification with concentrated sulfuric acid for 25 $\min$. Then, they were washed in running water for $5 \mathrm{~min}$ and dried in the shade on paper towel (Azêredo et al., 2010).

Saline stress was simulated using sodium chloride $(\mathrm{NaCl})$ as the solute, at the following osmotic potentials: $-0.2,-0.4,-0.6$, -0.8 and $-1.0 \mathrm{MPa}$, diluted in distilled and deionized water. The electrical conductivity in the solutions $(5.41,10.81,16.22,21.63$ and $27.04 \mathrm{dS} \mathrm{m}^{-1}$ ) was verified using a conductivity meter. For the control, distilled and deionized water was used to moisten the substrate. The electrical conductivity values of the $\mathrm{NaCl}$ solutions were obtained through the expression: Yos = RTC, in which: Yos = osmotic potential (atm); $\mathrm{R}=$ universal gas constant $\left(0.082\right.$ atm mol. $\left.\mathrm{L}^{-1} \mathrm{~K}^{-1}\right)$; $\mathrm{T}=$ temperature $(\mathrm{K}) ; \mathrm{C}=$ concentration $\left(\mathrm{mol} \mathrm{L}^{-1}\right)$; mol L-1 $\mathrm{x}$ molar mass of $\mathrm{NaCl}=\mathrm{g} \mathrm{L}^{-1}$ and $\mathrm{T}(\mathrm{K})=273+\mathrm{T}\left({ }^{\circ} \mathrm{C}\right)$ (Salisbury \& Ross, 1991).

The experimental design was completely randomized in a $3 \times 6$ factorial scheme (temperature $\mathrm{x}$ osmotic potential), with four replicates of 25 seeds.

The seeds were distributed on two paper towel sheets (Germitest), covered with a third sheet and organized in the form of a roll. The substrate was moistened with distilled water or $\mathrm{NaCl}$ solutions using an amount equivalent to 3 times the mass of the paper before hydration. The rolls were placed in 0.04-mm-thick transparent plastic bags to reduce water losses through evaporation. The treatments were evaluated using the following tests:

Germination - conducted in a Biochemical Oxygen Demand (B.O.D.) germinator regulated for constant temperature regimes of 25,30 and $35^{\circ} \mathrm{C}$. Evaluations were performed by daily counting normal seedlings (Brasil, 2009) for 21 days, when germination stabilized.

Germination speed index (GSI) - conducted along with the germination test, by daily counting normal seedlings, from 3 to 21 days, at the same time, and calculated through the formula proposed by Maguire (1962).

Seedling root and shoot length - the measurements were taken after the final count of the germination test, using a ruler graduated in centimeters, and the results were expressed in $\mathrm{cm}$.

Seedling dry matter - the normal seedlings of each replicate were placed in paper bags and dried in a forced-air oven at $70{ }^{\circ} \mathrm{C}$ until constant mass $(72 \mathrm{~h})$. After this period, seedlings were weighed on an analytical scale $(0.001 \mathrm{~g})$ and the results were expressed in $g_{\text {seedling }}{ }^{-1}$.

The data were subjected to analysis of variance by $\mathrm{F}$ test and polynomial regression through the program Sisvar, adopting linear and quadratic models with significance below $5 \%$ and of greater order $\left(\mathrm{R}^{2}\right)$, selecting the equation that best fitted the data.

\section{Results AND Discussion}

For all temperatures, germination percentage decreased as the osmotic potential decreased and the highest germination percentages (91, 93 and 89\%) were obtained when the seeds were germinated in substrate moistened with deionized water $(0.0 \mathrm{MPa})$ at temperatures of 25,30 and $35^{\circ} \mathrm{C}$, respectively (Figure 1). The temperatures of 25 and $30{ }^{\circ} \mathrm{C}$ promoted high seed germination, above $80 \%$, until the osmotic potential of -0.6 $\mathrm{MPa}$, from which there was a sharp decrease in germination until -1.0 $\mathrm{MPa}$; at this point, germination occurred only at temperature of $25^{\circ} \mathrm{C}$.

When $P$. moniliformis seeds were subjected to the temperature of $35^{\circ} \mathrm{C}$, germination percentage decreased until 
- $\left(25^{\circ} \mathrm{C}\right) \mathrm{y}=-135.71 \mathrm{x}^{2}-77.286 \mathrm{x}+84.286 \mathrm{R}^{2}=0.92$

- $\left(30^{\circ} \mathrm{C}\right) \mathrm{y}=-183.04 \mathrm{x}^{2}-96.036 \mathrm{x}+87.929 \mathrm{R}^{2}=0.97$

$\Delta \quad\left(35^{\circ} \mathrm{C}\right) \mathrm{y}=139.73 \mathrm{x}^{2}+237.87 \mathrm{x}+97.536 \mathrm{R}^{2}=0.92$

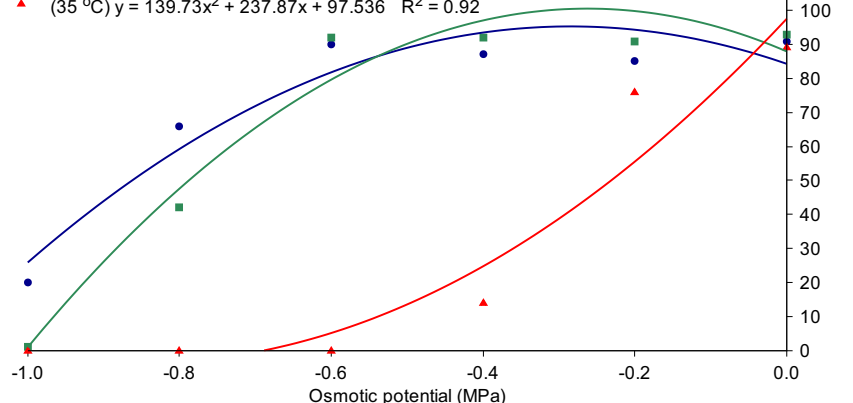

Figure 1. Germination of Piptadenia moniliformis seeds subjected to $\mathrm{NaCl}$-induced saline stress at different temperatures

the potential of $-0.4 \mathrm{MPa}$, evidencing that this temperature should not be used in the germination test.

As observed in the present study, the reduction in germination percentage of Caesalpinia ferrea seeds subjected to different salinity levels also led to a delay in the germination process (Freitas et al., 2010). Irrigation water salinity also decreased significantly the emergence of albizia seedlings as the salinity levels increased (Lima et al., 2015).

The association between environmental factors, such as relatively high temperatures and saline stress, harms in a more intense way the germination performance of the seed, probably for accelerating respiration and metabolic events, thus intensifying the toxic effects of salts and the deterioration (Guedes et al., 2011).

On the other hand, the highest temperature $\left(35^{\circ} \mathrm{C}\right)$ may have favored the disintegration of protein structures and, along with the toxic effect and the physiological drought caused by the saline osmotic potentials, probably led to reduction in seed germination.

The harmful effects on seed germination, observed under saline stress at $35^{\circ} \mathrm{C}$, were also reported for seeds of Peltophorum dubium (Spreng) Taub. (Alves et al., 2011).

The restriction in water absorption by the seeds occurs due to the reduction in the potential gradient between the soil and their surface, caused by the presence of salts, which interfere with soil water potential. Hence, the presence of salts may reach a high level and significantly harm germination (Martins et al., 2014).

Similar to the result for germination percentage, the germination speed index of $P$. moniliformis seeds was highly affected by the reduction in the osmotic potentials of the $\mathrm{NaCl}$ solutions, evidencing the effect of salinity on the delay of germination (Figure 2).

The highest GSI values, 74 and 76, occurred in the absence of salinity (0.0) for seeds incubated at temperatures of 25 and $30{ }^{\circ} \mathrm{C}$, respectively. Then, there were significant reductions to values lower than 5.0 and 0.0 when the seeds were subjected to saline concentration of $-1.0 \mathrm{MPa}$ at the previously mentioned temperatures. In seeds incubated at $35{ }^{\circ} \mathrm{C}$, the reduction in germination speed was more significant, with index of 37 at the potential of $0.0 \mathrm{MPa}$, which reached 6.0 at the potential of $-0.4 \mathrm{MPa}$. From this point on, germination did not occur.

The germination speed index proved to be efficient in the indication of negative effects of both the highest

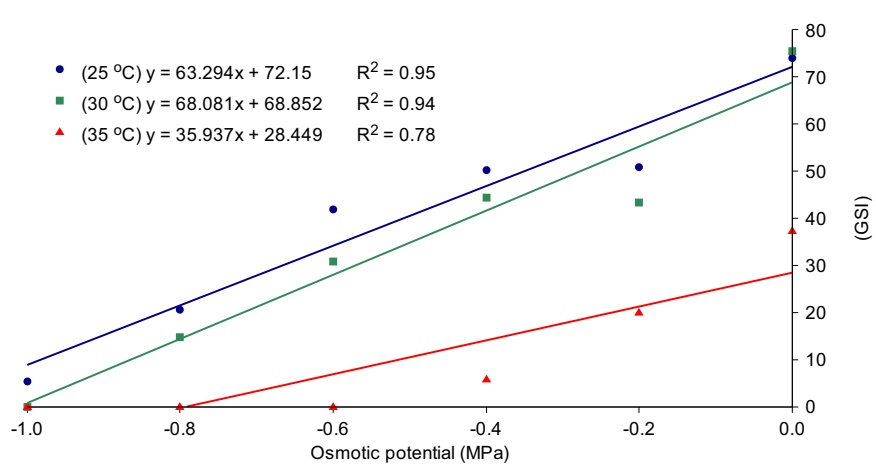

Figure 2. Germination speed index (GSI) of Piptadenia moniliformis seeds subjected to $\mathrm{NaCl}$-induced saline stress at different temperatures

temperature $\left(35^{\circ} \mathrm{C}\right)$ and the increasing levels of salts in the solution moistening the substrate, because the more negative is the osmotic potential of the environment, the lower is the germination speed of $P$. moniliformis seeds (Figure 2). These results emphasize the importance of water availability in the initial development stages of these seedlings, similar to the results for Bauhinia cheilantha (Oliveira et al., 2014) and Jatropha curcas (Andréo-Souza et al., 2010).

As observed, the water stress, caused by the increase in salinity, acts on the seed by retarding the absorption of water necessary to germination and, as a consequence, delaying the germination process (Betoni et al., 2011). Thus, germination speed can be considered as the first variable affected by the reduction in water availability due to saline stress (AndréoSouza et al., 2010; Oliveira et al., 2014).

Seeds of other species from the Caatinga also showed decrease in germination speed due to the increase in the saline concentration of the substrate, such as: Mimosa caesalpiniifolia Benth. (Ribeiro et al., 2008), Guazuma ulmifolia Lam. (Betoni et al., 2011), Anadenanthera colubrina var. cebil (Griseb.) Altschul.), Aspidosperma pyrifolium Mart. and Erythrina velutina Willd. (Dantas et al., 2014).

As to the temperatures, they also affected the germination speed of the seeds and the temperature of $35^{\circ} \mathrm{C}$ was the most harmful, regardless of the saline concentrations used, indicating that the deleterious effects of salinity are aggravated in germination under high temperatures. Similar results were also obtained by Guedes et al. (2011) in Chorizia glaziovii seeds, for the same temperature at which the increase in the saline concentration of the substrate caused reduction in seed germination and vigor.

As to shoot length (Figure 3), P. moniliformis seedlings showed a similar behavior at each temperature, with reduction in the values as the osmotic potential of the solution decreased. Seedlings subjected to temperatures of 25,30 and $35{ }^{\circ} \mathrm{C}$, and substrate moistened with water $(0.0$ $\mathrm{MPa})$, showed the highest values of shoot length (3.08, 2.98 and $3.10 \mathrm{~cm}$, respectively). The increase in salt concentration caused a more pronounced reduction in seedlings at the temperature of $35{ }^{\circ} \mathrm{C}$. Guedes et al. (2011), working with seeds of Chorisia glaziovii O. Kuntze, observed that shoot length was less affected by salinity at temperatures of 25 and 20-30 ${ }^{\circ} \mathrm{C}$, similar to the result of the present study.

For seeds of Zizyphus joazeiro Mart., Lima \& Torres (2009) observed significant difference in shoot length between the 


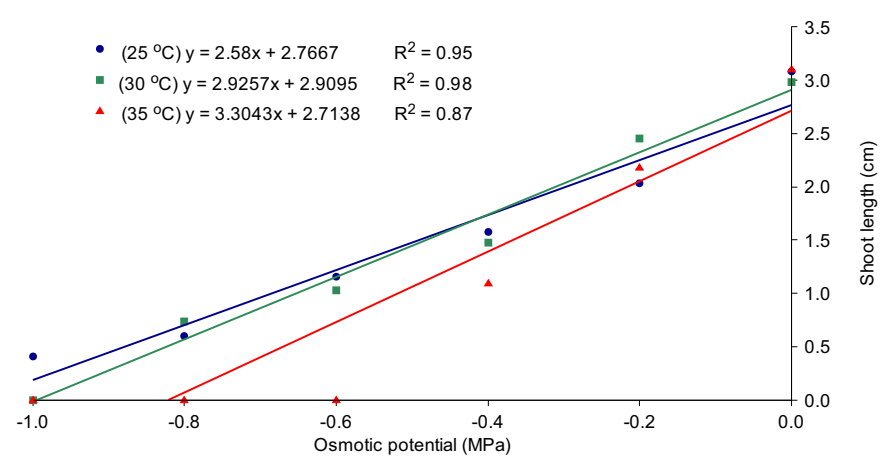

Figure 3. Shoot length of Piptadenia moniliformis seedlings subjected to $\mathrm{NaCl}$-induced saline stress at different temperatures

control and the other treatments, reporting that there was no significant growth of seedlings from the osmotic potential of $-0.6 \mathrm{MPa}$ of $\mathrm{NaCl}$.

The greatest length in the primary root of the seedlings $(3.71 \mathrm{~cm})$ was obtained when the seeds were placed to germinate at $30{ }^{\circ} \mathrm{C}$ in substrate moistened with water $(0.0$ $\mathrm{MPa})$. As observed for the previous variables, root growth of $P$. moniliformis seedlings was harmed by the increase in the saline concentration of the substrate, at the different temperatures evaluated. Nonetheless, at temperatures of 25 and $30^{\circ} \mathrm{C}$, root length values remained maximal until the osmotic potential of $-0.6 \mathrm{MPa}$, while the lowest root growth values were observed at $35{ }^{\circ} \mathrm{C}$, regardless of the osmotic potential (Figure 4).

The optimal temperature for cell division is approximately $30{ }^{\circ} \mathrm{C}$ for most species; therefore, it is close to the optimal temperature for primary root growth (Ferreira \& Borghetti, 2004). Results similar to those of the present study were observed for seeds of Diptychandra aurantiaca (Mart.) Tul. at temperatures of 25 and $30^{\circ} \mathrm{C}$ (Oliveira et al., 2013).

The highest values of dry matter occurred at temperatures of 25 and $30{ }^{\circ} \mathrm{C}$, regardless of the saline concentration. Seedlings showed quadratic responses to the increase in saline concentration when subjected to the temperatures of 25 and $30^{\circ} \mathrm{C}$, while there was a decreasing linear response at the temperature of $35{ }^{\circ} \mathrm{C}$. The solutions with osmotic potentials of -0.28 and $-0.26 \mathrm{MPa}$ promoted higher dry matter accumulation in seedlings at temperatures of 25 and $30{ }^{\circ} \mathrm{C}$, with value of $0.36 \mathrm{~g}$ for both temperatures. From these potentials on, there was a reduction in the dry matter. However, until the potential of $-0.6 \mathrm{MPa}$, there was a slight

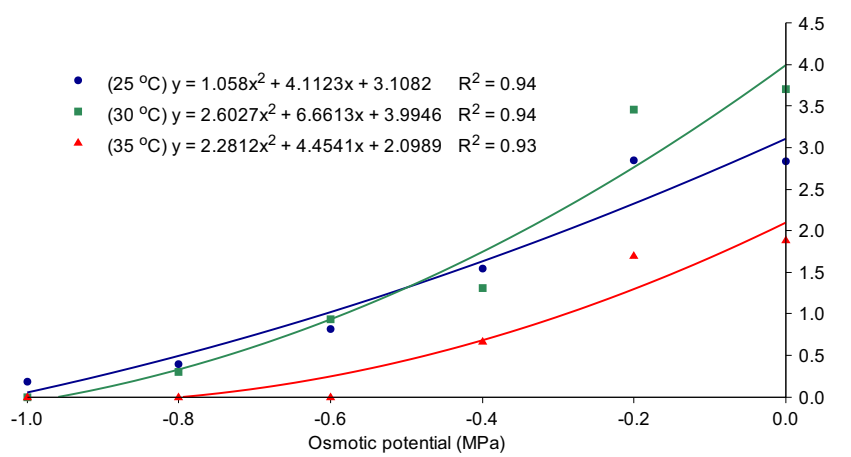

Figure 4. Primary root length of Piptadenia moniliformis seedlings subjected to $\mathrm{NaCl}$-induced saline stress at different temperatures reduction for the use of only deionized water $(0.0 \mathrm{MPa})$ (Figure 5).

Therefore, it is observed that salinity causes changes in the capacity of the plant to absorb, transport and use the ions necessary to growth and also reduces the metabolic assimilation rate and the activity of enzymes responsible for respiration and photosynthesis, thus decreasing the acquisition of energy for cell growth and differentiation in the tissues, and hence reducing embryonic axis elongation and dry matter production (Nobre et al., 2010).

The high limit of tolerance to saline stress, especially in the initial stages of its development, at the temperatures of 25 and $30^{\circ} \mathrm{C}$, provides an adaptive character to P. moniliformis, promoting high capacity of establishment of its seedlings in salt-affected areas.

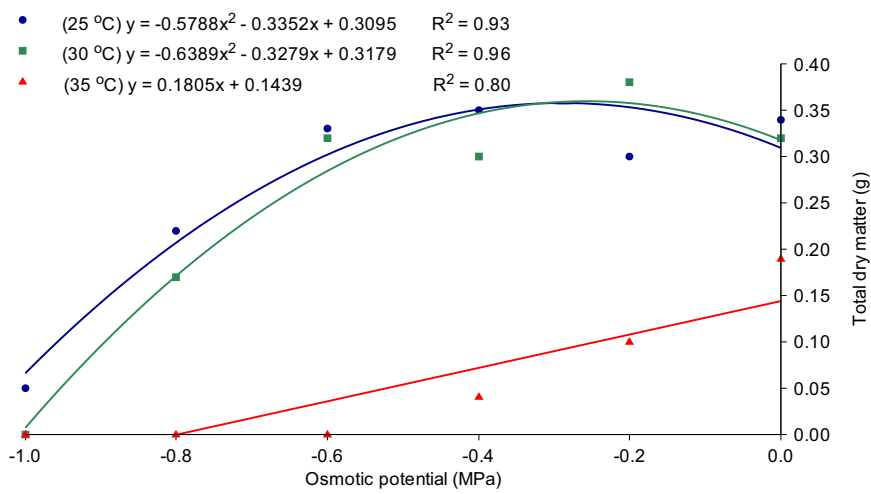

Figure 5. Total dry matter of Piptadenia moniliformis seedlings subjected to $\mathrm{NaCl}$-induced saline stress at different temperatures

\section{Conclusion}

P. moniliformis seeds germinated at temperatures of 25 and $30{ }^{\circ} \mathrm{C}$ tolerate saline concentrations with osmotic potential of up to $-0.6 \mathrm{MPa}$. From this point on, there is a progressive reduction in the physiological quality of the seedlings.

\section{Literature Cited}

Alves, E. U.; Guedes, R. S.; Gonçalves, E. D.; Viana, J. S.; Santos, S. S.; Moura, M. F. Effect of temperature and substrate on germination of Peltophorum dubium (Sprengel) Taubert seeds. Acta Scientiarum. Biological Sciences, v.33, p.113-118, 2011. http: //dx.doi.org/10.1590/S0100-29452012000400030.

Andréo-Souza, Y.; Pereira, A. L.; Silva, F. F. S. da.; Riberio-Reis, R. C.; Evangelista, M. R. V.; Castro, R. D. de.; Dantas, B. F. Efeito da salinidade na germinação de sementes e no crescimento inicial de mudas de pinhão-manso. Revista Brasileira de Sementes, v.32, p.8392, 2010. http://dx.doi.org/10.1590/S0101-31222010000200010.

Azerêdo, G. A.; Paula, R. C.; Valeri, S. V.; Moro, F. V. Superação de dormência de sementes de Piptadenia moniliformis Benth. Revista Brasileira de Sementes, v.32, p.49-58, 2010. http://dx.doi. org/10.1590/S0101-31222010000200006.

Betoni, R.; Scalon, S. P. Q.; Mussury, R. M. Salinidade e temperatura na germinação e vigor de sementes de mutambo (Guazuma ulmifolia Lam.) (Sterculaceae). Revista Árvore, v.35, p.605-616, 2011. http:// dx.doi.org/10.1590/S0100-67622011000400004 
Brasil. Ministério da Agricultura, Pecuária e Abastecimento. Regras para análise de sementes. Ministério da Agricultura, Pecuária e Abastecimento. Secretaria de Defesa Agropecuária. Brasília: MAPA/ ACS, 2009. 395p.

Dantas, B. F.; Ribeiro, R. C.; Matias, J. R.; Araújo, G. G. L. Germinative metabolism of Caatinga forest species in biosaline agriculture. Journal of Seed Science, v.36, p.194-203, 2014. http://dx.doi. org/101590/2317-1545v32n2927.

Ferreira, A. G., Borghetti, F. Germinação: Do básico ao aplicado. Porto Alegre: Artmed, 2004. 323p.

Freitas, R. M. O.; Nogueira, N. W.; Oliveira, F. N.; Costa, E. M.; Ribeiro, M. C. C. Efeito da irrigação com água salina na emergência e crescimento inicial de plântulas de jucá. Revista Caatinga, v.23, p.54-58, 2010.

Góis, V. A.; Torres, S. B.; Pereira, R. A. Germinação de sementes de maxixe submetidas a estresse salino. Revista Caatinga, v.21, p.64-67, 2008.

Guan, B.; Zhou, D.; Zhang, H.; Tian, Y.; Japhet, W.; Wang, P. Germination responses of Medicago ruthenica seeds to salinity, alkalinity and temperature. Journal of Arid Environments, v.73, p.135-138, 2009. http://dx.doi.org/10.1016/j.jaridenv.2008.08.009

Guedes, R. S.; Alves, E. U.; Galindo, E. A.; Barrozo, L. M. Estresse salino e temperaturas na germinação e vigor de sementes de Chorisia glaziovii O.Kuntze. Revista Brasileira de Sementes, v.33, p.279-288, 2011. http://dx.doi.org/10.1590/S0101-31222011000200010

IPECE - Instituto de Pesquisa e Estratégia Econômica do Ceará. Perfil básico municipal: Quixadá. Fortaleza: Governo do Estado do Ceará/ Secretaria de Planejamento e Coordenação, 2005. 10p.

Lima, B. G.; Torres, S. B. Estresses hídrico e salino na germinação de sementes de Zizyphus joazeiro Mart. (Rhamnaceae). Revista Caatinga, v.22, p.93-99, 2009. http://www.redalyc.org/articulo. oa? $\mathrm{id}=237117843016$

Lima, M. F. P.; Porto, M. A. F.; Torres, S. B.; Freitas, R. M. O.; Nogueira, N. W.; Carvalho, D. R. Emergência e crescimento inicial de plântulas de albízia submetidas à irrigação com água salina. Revista Brasileira de Engenharia Agrícola e Ambiental, v.19, p.106-112, 2015. http:// dx.doi.org/10.1590/1807-1929/agriambi.v19n2p106-112
Lorenzi, H. Árvores brasileiras: Manual de identificação e cultivo de plantas arbóreas nativas do Brasil. Nova Odessa: Plantarum, 2002. 197p.

Maguire, J. D. Speed of germination-aid in selection and evaluation for seeding emergence and vigor. Crop Science, v.2, p.176-177, 1962. http://dx.doi.org/10.2135/cropsci1962.0011183X000200020033x

Martins, C. C.; Pereira, M. R. R.; Lopes, M. T. G. Germinação de sementes de eucalipto sob estresse hídrico e salino. Bioscience Journal, v.30, p.318-329, 2014.

Nobre, R. G.; Gheyi, H. R.; Correia, K. G.; Soares, F. A. L.; Andrade, L. O. Crescimento e floração do girassol sob estresse salino e adubação nitrogenada, Revista Ciência Agronômica, v.41, p.358365, 2010. http://dx.doi.org/10.1590/S1806-66902010000300006

Oliveira, A. K. M.; Ribeiro, J. W. F.; Pereira, K. C. L.; Silva, C. A. A. Effects of temperature on the germination of Diptychandra aurantiaca (Fabaceae) seeds. Acta Scientiarum. Agronomy, v.35, p.203-208, 2013. http://dx.doi.org/10.4025/actasciagron. v35i2.15977

Oliveira, A. M. de; Linhares, P. C. F.; Maracajá, P. B.; Ribeiro, M. C.; Benedito, C. P. Salinidade na germinação e desenvolvimento de plântulas de aroeira (Myracroduon urundeuva FrAll). Revista Caatinga, v.20, p.39-42, 2007.

Oliveira, G. M.; Matias, J. R.; Silva, P. P.; Ribeiro, R. C.; Dantas, B. F. Germinação de sementes de aroeira-do-sertão (Myracrodruon urundeuva Fr. All.) e mororó (Bauhinia cheilantha (Bong) Stend.) em diferentes condutividades elétricas. Revista SODEBRAS, v.9, p.115-122, 2014.

Ribeiro, M. C. C.; Barros, N. M. S.; Barros Júnior, A. P.; Silveira, L. M. Tolerância do sabiá (Mimosa caesalpiniifolia Benth.) à salinidade durante a germinação e o desenvolvimento de plântulas. Revista Caatinga, v.21, p.123-126, 2008.

Salisbury, F. B.; Ross, C. W. Plant physiology. 4.ed. Belmont: Wadsworth, 1991. 682p. 